\title{
PENDIDIKAN KARAKTER: ANALISA PEMIKIRAN IBNU MISKAWAIH
}

\author{
Harpan Reski Mulia \\ Universitas Islam Negeri (UIN) Sunan Kalijaga Yogyakarta \\ email: harpanreskimulia@gmail.com
}

\begin{abstract}
Character Building is very important to discuss after the moral crisis that has happened a lot lately. In addition to, Indonesia lacks figures who can be used as a role model. That done because many public figures commited the crimes such as corruption, collusion, prostitution, and so on. Ibnu Miskawaih is one of the Islamic philosophers who touches on the concept of character education in his book tabiib al-akblak wa tahir al-a'raf. By literature studies, this paper attempts to describe the concept of character education offered by Ibnu Maskawaih, namely The Golden (The Doctrin of The Mean). He stated that buman character is built from four foundations, namely restraint, courage, wisdom, and justice. Ibnu Miskawaih views education as a means of instilling noble character, humanizing humans, individual socialization, and instilling shame. Therefore, the thought of Ibn Miskawaih is suitable for this era of morality crisis like today.
\end{abstract}

Keywords: Education of Character, The Thought of Ibnu Miskawaih

\begin{abstract}
Abstrak: Pendidikan Karakter merupakan hal yang sangat penting untuk dibahas mengingat krisis moral marak yang terjadi belakangan ini. Selain itu, Indonesia juga kekurangan tokohtokoh yang dapat dijadikan teladan. Hal ini disebabkan para figure pablik sekarang banyak yang melakukan kriminalitas seperti korupsi, kolusi, prostitusi, dan lain sebagainya. Ibnu Miskawaih adalah salah satu tokoh filsafat Islam yang menyentuh konsep tentang pendidikan karakter dalam bukunya tahrib al-akblak wa tahir al-a'raf. Dengan menggunakan studi literature, tulisan ini berusaha untuk memaparkan konsep pendidikan karakter yang ditawarkan oleh Ibnu Maskawaih yang dikenal dengan jalan tengah. Ia mengungkapkan bahwa karakter manusia terbangun dari empat landasan yaitu menahan diri, keberanian, kebijaksanaan, dan keadilan. Ibnu Miskawaih memandang pendidikan sebagai sarana menanamkan akhlak mulia, memanusiakan manusia, sosialisasi individu, dan menanamkan rasa malu. Sehingga, pemikiran ibnu Miskawaih ini sangat cocok digunakan di era krisis moralitas seperti sekarang ini.
\end{abstract}

Kata kunci: Pendidikan Karakter, Pemikiran Ibnu Miskawaih 


\section{PENDAHULUAN}

Pendidikan karakter menjadi bahasan yang sangat strategis dalam konteks pendidikan di Indonesia. Hal ini berkaitan dengan krisis moral yang terjadi belakangan ini. Di mana, hampir semua kasus yang terjadi akibat dari kegagalan pendidikan karakter yang diberikan oleh lembaga-lembaga pendidikan. Kasus-kasus yang berskala nasional misalnya, banyak dipicu oleh kurang dalamnya proses internalisasi pendidikan akhlak yang diberikan disekolah-sekolah. Dalam konteks kekinian, nilai-nilai etika pendidikan yang baik sangat dibutuhkan untuk membentuk karakter generasi muda yang ditanamkam melalui jalur pendidikan. Hal ini disebabkan bahwa, manusia yang semakin modern mengalami krisis moral dan etika yang menjadi prinsip-prinsip hidup bermasyarakat.

Krisis yang banyak terjadi di Indonesia salah satunya adalah krisis tokoh-tokoh yang bisa diteladani, banyak kasus-kasus kriminal yang dilakukan oleh orang yang menjadi figur di masyarakat, seperti kasus korupsi kolusi dan sebagainya. Begitu juga di kalangan pelajar yang terjadi adalah perilaku-perilaku yang bertentangan dengan moral atau akhlak Islam seperti seks bebas, narkoba, tawuran, dan lain sebagainya yang berdampak bagi perkembangan jiwa anak didik (Unayah dan Sabarisman, 2015). Belum lagi pengaruh budaya asing yang dengan mudah diakses oleh anak-anak melalui situs-situs negatif yang beredar di dunia maya (internet). Oleh karena itu, pembentukan dan pembinaan etika yang baik sejak dini dalam konteks pendidikan perlu dilakukan.

Pengembangan pendidikan karakter tidak bisa dilepaskan dari pemberian ranah akhlak dalam pendidikan. Dalam perspektif muatan, pendidikan karakter harus terwujudkan pada setiap kontens kurikulum pendidikan dari berbagai disiplin ilmu yang diajarkan di sekolah maupun di madrasah. Oleh karena itu, sangat urgen jika dilakukan kajian tentang konsepkonsep etika Islam yang menjadi pilar pengembangan pendidikan karekter di tanah air, dengan jalan mengkaji konsep etika yang digagas oleh ulama Islam, diantaranya adalah konsep etika menurut Ibnu Maskawaih yang bisa dijadikan sebagai rujukan, untuk menggagas konsep ideal dan praksis tentang pendidikan karakter yang bersumber dari pemikiran para ulama atau filosof muslim.

Untuk itu dalam mengkaji tentang pemikiran Ibnu Maskawaih, penulis menggunakan studi literatur atau kepustakaan dari berbagai referensi dan data yang ada. Kemudian, data tersebut dikemas sebagai bahan informasi yang dapat memberikan gambaran mengenai pendidikan karakter menurut Ibnu Maskawaih dan relevansinya di era modern. 


\section{PEMBAHASAN}

\section{Konsep yang Melandasi Pemikiran Pendidikan Ibnu Miskawaih}

Dari berbagai karyanya, Ibnu Miskawaih banyak membahas persoalan-persoalan filsafat. Pemikirannya tentang pendidikan bertumpu pada tema manusia, jiwa, dan akhlak (Mahmud, 2011) berikut pemaparannya:

1. Konsep Manusia

Ketika orang memahami kata al-insan berasal dari kata al-nasyan, seakan-akan ia memberikan justifikasi bahwa, ketika manusia tidak menepati janji atau mengerjakan hal-hal yang bersifat negative dengan alasan lupa merupakan kesalahan yang wajar-wajar saja. Memang manusia selalu luput dari kesalahan, sebagaimana yang telah disabdakan oleh Nabi Muhammad saw: "Setiap keturunan Adam pasti berbuat kesalahan dan sebaik-baik kesalahan adalah pertaubatan". Bahkan dikatakan pula dalam pepatah "manusia adalah tempat salah dan lupa".

Kata Insan ialah bentuk mufrat/tunggal, sama dengan kata anas. Insan menurut Ibn Madzur dapat diambil dari tiga akar kata yaitu; Anas, Annisa, Nasia.

a) Annas yang artinya :

1) 'Abshara: melihat, bernalar, dan berpikir. Dengan itu manusia dapat mengambil pelajaran dari apa yang dilihatnya.

2) 'Alima: mengetahui, berilmu. Dengan ilmu manusia dapat membedakan antara yang baik dan yang salah.

3) Istadæana: meminta izin, makhluk yang beradab. Dengan ini manusia cenderung untuk meminta izin melakukan sesuatu yang bukan kewenangannya. Dari kata ini, insan dimaknai sebagai makhluk yang mempunyai daya nalar, berilmu, dan beradab.

b) Anisa: artinya alifaibu wa sakana qalbubu bibi: jinak, ramah, lawan kata tawakhasya: buas. Dari kata ini, dapat disimpulkan manusia adalah makhluk yang bersahabat dan ramah dalam pergaulan.

c) Nasia artinya dliddu tadzakeara, yaitu lupa.

Dengan demikian dapat kita simpulkan, pengertian al-insan adalah makhluk yang mempunyai daya nalar dan daya pikir yang dengannya dapat maju dan berkembang. Ia berilmu, yang dengan ilmu dapat membedakan antara yang benar dan yang salah. Ia beradab, tidak suka merampak dan mengambil hak orang lain tanpa izin. Ia ramah dalam pergaulan, bersahabat, serta dapat menyesuaikan diri dengan perkembangan dan lingkungan. Ia kadang lupa dan tidak selalu ada dalam kebenaran. 
Menurut pandangannya, manusia adalah makhluk yang memiliki keistimewaan karena dalam kenyataannya manusia memiliki daya pikir (Miskawaih, 1994). Berdasarkan daya pikir tersebut, manusia dapat membedakan antara yang benar dan yang salah, serta yang baik dan yang buruk. Dan manusia yang kemanusiaannya paling sempurna ialah mereka yang paling benar cara berpikirnya serta yang paling mulia usaha dan perbuatannya. Selain itu, Ibnu Miskawaih berpendapat bahwa untuk mewujudkan kebaikan, manusia harus membina kerjasama. Usaha untuk mewujudkan kebaikan merupakan indikator dari tingkat kesempurnaan dan tujuan dari penciptaan manusia itu sendiri.

2. Konsep Jiwa

Ibnu Miskawaih menjabarkan bahwa dalam diri manusia selain tedapat tubuh, juga terdapat sesuatu yang bukan tubuh, yang oleh Ibnu Miskawaih disebut dengan jiwa. Sebagai argument untuk menjelaskan adanya jiwa, Ibnu Miskawaih mengemukakan kenyataan tentang penerimaan atau rekaman kesadaran kita terhadap berbagai bentuk yang berasal dari benda-benda yang bersifat jasmani atau bersifat empiris. Bila yang merekam atau menerima itu bersifat jasmani, pastilah jasmani hanya bisa menerima sesuatu bentuk baru yang menggantikan bentuk yang lama. Benda jasmani hanya dapat menerima satu bentuk dalam satu saat, dan hanya bisa menerima bentuk yang berbeda pada yang waktu lain (Rahmaniyah, 2010).

Ibnu Miskawaih menonjolkan kelebihan jiwa manusia atas jiwa binatang dengan adanya kekuatan berfikir yang menjadi sumber pertimbangan tingkah laku, yang selalu mengarah kepada kebaikan. Lebih jauh menurutnya, jiwa manusia mempunyai tiga kekuatan yang bertingkat-tingkat.

a) Daya nafsu (al-Nafs al-Babimiyyah) yang buruk. Jiwa ini menjadi dasar syahwat, usaha mencari makan, kerinduan untuk menikmati makanan, minuman, perkawinan, serta berbagai kenikmatan individu lainnya. Pusat daya jiwa ini ada di dalam hati.

b) Daya Berani (al-Nafs al-Sabua'iyyah) yang sedang. Jiwa ini menjadi dasar kemarahan, tantangan, dan keberanian atas hal yang menakutkan. Pusatnya di hati.

c) Daya berfikir (al-Nafs al-Natiqab) yang baik. Jiwa ini merupakan jiwa yang menjadi dasar berfikir, membedakan, dan menalar hakikat segala sesuatu. Pusatnya pada otak.

Manusia dikatakan menjadi manusia yang sebenarnya jika memiliki jiwa yang cerdas. Dengan jiwa yang cerdas itu, manusia tingkat derajatnya dan dengan itu pula manusia dapat dibedakan dengan binatang. Berkenaan dengan hal ini, Ibnu Miskawaih mengatakan bahwa jiwa yang rendah atau buruk mempunyai sifat ujub, sombong, pengolok-olok, penipu, dan 
hina. Sedangkan jiwa yang cerdas mempunyai sifat adil, harga diri, berani, pemurah, dan cinta (Rahmaniyah, 2010).

3. Konsep Akhlak

Menurut Ibnu Miskawaih, pada dasarnya karakter dari sifat manusia yang harus dibangun dengan menggunakan teori The Golden Mean tersebut ada 4 karakter, yang menjadi pondasi bagi pengembangan karakter mulia manusia yakni al-Iffat (menahan diri/self control), al-Syaja'at (keberanian), dan al-Hikmat (kebijaksanaan) serta al-Adalat (keadilan). Keempat karakter tersebut merupakan pokok-pokok akhlak manusia. Dan sifat-sifat lain yang berupa keutamaan akhlak manusia merupakan turunan atau cabang dari empat pokok keutamaan akhlak tersebut. Sifat-sifat utama disebut sebagai al-fadlilah, berada dalam posisi tengah (alwasath), dari dua ektrimitas karakter atau sifat manusia yang tidak baik. Dua kutub ekstrim tersebut adalah al-Tafrith (ekstrem kekurangan) dan al-Ifrath (ekstrem kelebihan). Menurut Ibnu maskawaih bahwa setiap keutamaan karakter manusia mempunyai dua ekstrem, dan yang berada ditengah adalah karakter yang terpuji (Miskawaih, 1994).

Posisi tengah yang dimaksud adalah standar atau prinsip umum yang berlaku bagi manusia. Posisi tengah yang sebenarnya adalah (al-wasath al-haqiqi) adalah satu, yang disebut al-fadîlah (keutamaan), yang disebut juga al-khat al-mustaqîm (garis lurus). Empat pokok keutamaan dengan ekstrem kekurangan dan ekstrem kelebihan data dipetakan dalam tabel berikut (Abidin, 2014):

Tabel 1. Empat Pokok Keutamaan dengan Ekstrem Kekurangan dan Ekstrem Kelebihan Data

\begin{tabular}{|c|c|c|}
\hline $\begin{array}{c}\text { Ekstrem Kekurangan } \\
(\text { Al-Tafrith })\end{array}$ & $\begin{array}{l}\text { Posisi Tengah } \\
\text { (Al-Wasath) }\end{array}$ & $\begin{array}{l}\text { Ekstrem Kelebihan } \\
\text { (Al-Ifrath })\end{array}$ \\
\hline Kedunguan (al-Balab) & Kebijaksanaan (al-Hikmah) & Kelancangan (al-safab) \\
\hline Pengecut (al-Jubn) & Keberanian (al-Syaja'ab) & Nekat (al-Tathawmur) \\
\hline Dingin Hati (al- Khumud) & $\begin{array}{l}\text { Menahan Diri/ menjaga kesucian (al- } \\
\text { Iffat })\end{array}$ & Rakus/ loba (al-Syarah \\
\hline Teraniaya & $\begin{array}{l}\text { Keadilan (al-Adalat })=\text { (kombinasi } \\
\text { dari ketiga keutamaan diatas } \\
\text { menghasilkan keadilan) }\end{array}$ & Berbuat Aniaya \\
\hline
\end{tabular}

\section{Pendidikan Karakter Perspektif Ibnu Maskawaih}

1. Manusia Perlu Dididik

Ibn Miskawaih memberikan statement tentang karakter (watak) manusia. Bahwa manusia memiliki dua macam karakter, pertama, adalah tabii (alami) dan kedua, karakter yang diperoleh melalui kebiasaan dan latihan (Rahmaniyah, 2010). Para cendikiawan klasik berbeda 
pendapat tentang hal ini. Sebagian mengatakan bahwa watak itu alami dan tidak dapat diubah, sedangkan sebagian yang lain mengatakan tidak ada satupun pada watak itu yang alami, semuanya dapat berubah.

Ibnu Miskawaih berpendapat, bahwa watak itu tidak alami. Kita diciptakan atas dasar menerima watak, namun kita berubah berkat pendidikan dan pengajaran. Pendapat inilah yang menjadi pilihan Ibnu Miskawaih karena sesuai dengan realita yang sering dijumpai dalam kejadian nyata. Pendapat pertama (yang mengatakan watak itu alami dan tak dapat dididik) mengesampingkan kekuatan tamyiz (penalaran) serta akal dan menolak segala upaya serta membiarkan manusia tidak beradab, menelantarkan para remaja dan anak-anak tanpa pendidikan (Rahmaniyah, 2010).

Kemudian Ibnu Miskawaih mengemukakan pendapat golongan Ruwwaqiyyun, Jalinus dan pendapat Aristoteles tentang watak manusia. Golongan Rawwaqiyyun berpendapat bahwa watak itu dasarnya baik, kemudian karena pengaruh pergaulan watak yang baik itu menjadi buruk. Sedangkan Galen berpendapat bahwa sebagian watak manusia pada dasarnya (alami) jahat, sebagian lagi mengatakan watak itu dasamya baik, di antara mereka ada yang mengatakan dasar watak itu tengah-tengah antara baik dan buruk. Mereka yang wataknya alami baik, mereka tidak akan berubah menjadi buruk. Sedang mereka yang wataknya alami buruk, mereka tidak akan berubah menjadi baik (Majidi, 1997). Mereka yang wataknya berada di tengahtengah di antara baik dan buruk dapat berubah menjadi baik jika mendapat pengaruh pendidikan yang baik dan berubah menjadi buruk jika mendapat pengaruh pendidikan yang buruk. Kemudian Ibnu Miskawaih mengutip pendapat Aristoteles yang dijadikannya pegangan (Rahmaniyah, 2010).

Menurut Aristoteles orang jahat ataupun orang yang mempunyai watak buruk dapat berubah dengan pendidikan, namun tidak mutlak. Pengajaran dan pendidikan yang berkelanjutan serta bimbingan yang baik yang diupayakan manusia tentulah akan memberi pengaruh yang berbeda-beda terhadap bermacam-macam orang. Ada di antara mereka yang menerima pendidikan dengan cepat, sedang sebagian yang lain menerimanya dengan lambat untuk menuju keutamaan (Rahmaniyah, 2010).

\section{Dasar Pendidikan}

Dasar merupakan landasan bagi berdirinya sesuatu dan ia berfungsi sebagai pemberi arah terhadap tujuan yang akan dicapai (Mahmud, 2011). 
a. Syariat sebagai dasar pendidikan. Ibnu Miskawaih tidak menjelaskan secara pasti apa yang menjadi dasar pendidikan. Akan tetapi, ia menyatakan bahwa syariat agama merupakan faktor penentu bagi lurusnya karakter manusia.

b. Pengetabuan psikologi sebagai dasar pendidikan. Ibnu Miskawaih menegaskan adanya hubungan antara pendidikan dan pengetahuan tentang jiwa. Pembentukan karakter baik tersebut dapat tercapai jika kita memahami makna jiwa, mulai permintaan, tujuan, kekuatan atau daya, dan malakah-nya. Jiwa yang dibina dengan tepat akan menjadikan manusia tersebut mencapai kesempurnaan. Pembinaanjiwa tersebut dapat dilakukan melalui pendidikan.

\section{Konsep Pendidikan}

Ibn Miskawaih membangun konsep pendidikannya yang bertumpu pada pendidikan akhlak. Karena dasar pendidikan Ibn Miskawaih dalam bidang akhlak, maka konsep pendidikan yang dibangun adalah pendidikan akhlak yang meliputi:

a. Tujuan Pendidikan

Ibnu Miskawaih mengisyaratkan bahwa tujuan pendidikan adalah terbentuknya pribadi yang berakhlak mulia, yang disebut sebagai isbah al-khuluq asy-syarif, yakni pribadi yang mulia secara substansial dan esensial. Selain itu, tujuan pendidikan juga identik dengan tujuan hidup manusia. Tercapainya tujuan pendidikan merupakan langkah bagi tercapainya tujuan hidup manusia yang terakhir, yaitu kebaikan, kebahagiaan, dan kesempurnaan (Mahmud, 2011).

b. Fungsi Pendidikan

Menurut Ibn Miskawaih, fungsi pendidikan adalah sebagai berikut:

1) Menanamkan akhlak mulia. Bagi Ibn Miskawaih, pembentukan akhlak mulia merupakan tujuan pendidikan, sekaligus sebagai fungsi pendidikan. Nilai-nilai akhlak mulia yang perlu ditanamkan dan dibiasakan itu pada aspek rohani seperti jujur, tabah, sabar, dan lain-lain. Juga pada aspek jasmani seperti adab berpakaian, berbicara, dan lain-lain (Mahmud, 2011).

2) Memanusiakan manusia. Ibn Miskawaih menyatakan bahwa tugas pendidikan adalah menundukkan manusia sesuai dengan substansinya sebagai makhluk yang termulia. Selain itu, pendidikan bertugas mengangkat manusia dari tingkat terendah pada tingkat tinggi (Mahmud, 2011). 
3) Sosialisasi individu. Sejumlah individu harus bersatu untuk mencapai kebahagiaan Bersama sehingga satu sama lainnya saling menyempurakan. Masing-masing individu menjadikan dirinya seperti satu tubuh yang saling menunjang (Mahmud, 2011).

4) Menanamkan rasa malu. Rasa malu yang dimaksud disini adalah rasa takut lahirnya sesuatu yang jelek dari dirinya. Ibnu Miskawaih mengatakan bahwa tanda awal perkembangan akal adalah timbulnya rasa malu karena hal itu menunjukan bahwa anak sudah menginsafi tentang keburukan (Majidi, 1997).

c. Materi Pendidikan

Pada materi pendidikan Ibnu Miskawaih ditujukan agar semua sisi kemanusiaan mendapatkan materi didikan yang memberi jalan bagi tercapainya tujuan pendidikan. Materi-materi yang dimaksud diabdikan pula sebagai bentuk pengabdian kepada Allah SWT. Materi pendidikan akhlaknya yaitu : hal-hal yang wajib bagi kebutuhan tubuh manusia, dan hal-hal yang wajib bagi jiwa. Materi pendidikan akhlak yang wajib bagi kebutuhan tubuh manusia antara lain shalat, puasa dan sa'i. Selanjutnya materi pendidikan ahklak yang wajib dipelajari bagi kebutuhan jiwa dicontohkan oleh Ibnu Miskawaih dengan pembahasan akidah yang benar, mengesakan Allah dengan segala kebesaran-Nya serta motivasi senang kepada ilmu dan materi yang terkait dengan keperluan manusia dengan manusia dicontohkan dengan materi ilmu muammalat, perkawinan, saling menasehati, dan lain sebagainya ( Hariyanto, dan Anjaryati, 2016).

d. Metode dan Alat Pendidikan

1) Metode alami. Metode alamiah itu bertolak dari pengamatan terhadap potensi-potensi insani. Mana yang muncul terlebih dahulu, maka pendidikan diarahkan kepada pemenuhan kebutuhan potensi yang lahir dahulu itu, kemudian kepada kebutuhan potensi berikutnya yang lahir sesuai dengan hukum alam. Potensi yang muncul pertama kali adalah gejala umum yang ada pada tingkat kehidupan hayawani dan nabati, kemudian terus-menerus lahir suatu gejala khusus yang berbeda dengan gejala potensi lainnya sampai menjadi tingkat kehidupan insani. Maka dari itu kata Miskawaih, wajib bagi kita mulai dengan kecenderungan akan makan, yang muncul pada diri kita dengan jalan memenuhi kebutuhan kecenderungan. Lalu muncul kecenderungan ghodlabiyah dan cinta kemuliaan, kita didik dengan jalan memenuhi kecenderungan itu. Kemudian terakhir lahir kecenderungan kepada ilmu pengetahuan, maka kita didik dengan jalan memenuhi kecenderungan itu. Urutan kemunculan inilah yang kami (Miskawaih) maksudkan thabi'iy (alami), karena didasarkan proses kejadian manusia, yakni pertama 
kali embrio lalu bayi kemudian orang dewasa. Potensi-potensi ini lahir berurutan secara alamiah. Ide pokok dari thariqun thabi'iyyun dari Miskawaih adalah bahwa pelaksanaan kerja mendidik itu hendaknya didasarkan atas perkembangan lahir batin manusia. Setiap tahap perkembangan manusia mempunyai kebutuhan psycho-phisiologis dan cara mendidik hendaklah memperhatikan kebutuhan ini sesuai dengan tahap perkembangannya (Hariyanto, dan Anjaryati, 2016).

2) Nasihat dan tuntutan sebagai metode pendidikan. Ibn Miskawaih menyatakan, supaya anak menaati syariat dan berbuat baik, diperlukan nasihat dan tuntrunan. Dalam AlQuran, apa yang dikemukakan Ibn Miskawaih banyak ditemukan, seperti dalam surat Luqman: 1 3-19. Ini menunjukkan betapa pentingnya nasihat dalam interaksi pendidik dengan subjek didik (Mahmud, 2011).

3) Ancaman, hardikan, hukuman, dan pukulan sebagai metode pendidikan. Ibn Miskawaih mengindikasikan banyak sekali yang dapat dilakukan dalam mendidik, seperti tertera di atas dan dilaksanakan secara akmat sesuai dengan tuntutan yang diperlukan. Artinya, jika subjek didik tidak melaksanakan tata nilai yang telah diajarkan, mereka diberi sanksi berbagai para sehingga mereka kembali pada tatanan nilai yang ada. Akan tetapi, pemberian sanksi harus bertahap dalam pelaksanaannya, yaitu ancaman, hardikan, kemudian pukulan (bersifat jasmani), dan hukuman baik bersifat jasmani maupun rohani (Mahmud, 2011).

4) Sanjungan dan pujian sebagai metode pendidikan. Ibnu Miskawaih menegaskan, jika subjek didik melaksanakan syariat dan berperilaku baik, dia perlu dipuji. Selanjutnya, jika ia didapati melakukan perbuatan yang melanggar syariat dan budi pekerti mulia, anak didik terlebih dahulu, jangan langsung dicerca, apalagi di depan orang banyak.

\section{Relevansi Pemikiran Ibnu Maskawaih di Era Modern: Sebuah Analisis}

Pendidikan karakter menurut Ibnu Maskawaih bisa diterapkan dengan menggunakan strategi secara makro maupun mikro, karena sifat atau nilai-nilai kemanusian yang melekat dalam pemikiran etika Ibnu Maskawaih, misalnya manusia memang harus bijaksana, berani, mengendalikan diri dan adil. Keempat nilai/karakter tersebut menjadi bagian dengan integral dari dari karakter universal manusia, dan karakter itu juga berlaku pada manusia Indonesia, yang mayoritas beragama Islam. Bisa dianggap bahwa empat karekter tersebut merupakan pilar-pilar utama bagi pembentukan karakter manusia seutuhnya. Tampaknya nilai-nilai universal tersebut juga dikembangkan dalam pendidikan karakter yang sedang menjadi trend pendidikan dewasa ini ( Abidin, 2014). 
Dalam prakteknya pendidikan karakter dapat didesain dengan memasukkan nilai-nilai pendidikan karakter dalam kurikulum pendidikan nasional. Pelaksanaan pendidikan karakter di Indonesia akan disajikan secara integral dalam muatan kurikulum tahun 2013. Berarti setiap mata pelajaran yang diberikan pada setiap satuan pendidikan atau institusi pendidikan formal harus mengembangkan aspek penanaman karakter. Dalam persepektif ini nilai-nilai karakter yang dikembangkan oleh Ibnu Maskawaih bisa dijadikan sebagai salah satu rujukan pelaksanaan pendidikan di Indonesia terutama dalam konteks pelaksanaan pendidikan Islam, maupun pelaksanaan pendidikan nasional di Indonesia. Nilai-nilai atau karakter yang diharapkan adalah terbentuknya kepribadian yang dilandasi norma-norma agama, budaya dan etika bangsa Indonesia ( Abidin, 2014).

Tugas pendidik dalam pembinaan karakter Islami sangat mulia dan berdimensi pada upaya pembersihan hati, jiwa dan ruhani peserta didik. Guru (pendidik) harus senantiasa membiasakan sifat-sifat yang mulia, bukan hanya mengembangkan aspek intelektual (kognitif) saja melainkan juga menanamkan kepribadian yang mulia sebagai sebagai figur pendidik Islam. Oleh kerena itu dalam perspektif akhlak seorang pendidik yang baik supaya mampu mentransfer pembentukan karakter yang mulia di antaranya harus mempunyai karakterkarakter antara lain berkarakter robbaniyah (pendidik dalam arti yang berorientasi pada Tuhan, memelihara sifat mulia), ikhlas, sabar, adil, zuhud, bersih jiwa dan raganya, dan yang terpenting adalah meniatkan tugasnya untuk mendekatkan diri kepada Allah SWT, rasional, tidak emosional, dan berjiwa sosial ( Abidin, 2014).

Demikian juga dari aspek siswa (peserta didik), pendidikan karakter Islam harus memperhatikan ciri khusus peserta didik. Pertama, peserta didik bukanlah miniatur orang dewasa, tetapi memiliki dunianya sendiri. Kedua, peserta didik adalah manusia yang memiliki deferiansi periodesasi perkembangan dan pertumbuhan. Ketiga, peserta didik adalah manusia yang memiliki kebutuhan, yaitu kebutuhan jasmani, kasih sayang, rasa aman, harga diri, aktualisasi diri. Keempat, peserta didik adalah makhluk Allah swt yang mempunyai perbedaan bakat dan minat. Kelima peserta didik mempunyai dua potensi jasmani dan rohani, dan mempunyai potensi absolut yaitu fitrah bertuhan dan berperi kemanusiaan. Dengan memperhatikan potensi khusus yang dimiliki peserta didik diharapkan pendidikan karakter islami oleh pendidik dapat berjalan dengan baik (Abidin, 2014).

Dalam persepektif praktis, pendidikan karakter Islam dapat diupayakan dengan mendisain kurikulum pendidikan dengan alternatif yang mengggunakan pilihan model pendidikan karakter. Pendidikan karakter diberikan dengan model terpisah sebagai mata pelajaran tersendiri, atau dengan model terintegrasi dalam setiap mata pelajaran, atau model 
yang diberikan diluar pengajaran, bahkan bisa dilakukan dengan model gabungan. Hal ini mengindikasikan bahwa model-meodel pendidikan karakter bersifat terbuka dan fleksibel untuk diterapkan dalam dunia pendidikan (Abidin, 2014).

Sebagaimana di jelaskan diatas bahwa pemikiran Ibnu Maskawaih dibangun bertumpu pada pendidikan akhlak. Tujuan pendidikan akhlak Ibnu Maskawaih berupa terbentuknya karakter (akhlak) yakni terbentuknya sikap batin yang mampu mendorong secara spontan untuk melahirkan semua perbuatan yang bernilai baik, sehingga mencapai kesempurnaan dan memperoleh kebahagiaan sejati dan sempurna. Jika seorang guru telah mampu menciptakan anak didik dalam taraf pencapaian kebijaksanaan yang tinggi Ibnu Maskawaih menganggap bahwa guru tersebut telah berada dalam posisi yang tinggi dan berderajat al-mu'alim al-misal, alhakim, atau al-mualim al-hikmat. Derajat seperti itu menurut Maskawaih sesuai dengan konsepnya tentang manusia ideal (al- Insān al-Fadîlat). Mereka yang berada dalam garis posisi tertinggi tersebut sejajar dengan posisi para Nabi, meskipun dia bukan Nabi, terutama dalam hal sifat cinta kasih yang dimilikinya (Abidin, 2014).

Dari pemaparan diatas juga, hemat penulis bahwa Ibnu Miskawaih dalam menggunakan kata "karakter" sepertinya tidak terlalu membedakan penggunaannya dengan kata watak, etika dan akhlak. Penggunaan ketiga kata ini pada hakikatnya sama-sama merujuk kepada pengertian dari karakter. Sebagaimana yang di kutip dalam buku filsafat pendidikan Islam, Maragustam mengatakan bahwa karakter adalah sifat utama yang terukir, baik pikiran, sikap, perilaku maupun tindakan, yang melekat dan menyatu kuat pada diri seseorang yang membedakannya dengan orang lain (Maragustam, 2014). Sehingga dalam makalah ini, penggunaan kata akhlak, watak, etika dan karakter juga memiliki arti yang sama. Walaupun menurut tata bahasa, ketiga kata tersebut memiliki arti yang berbeda.

Pendidikan karakter yang dipopulerkan oleh Ibnu Miskawaih ini didasarkan pada doktrin jalan tengah. Doktrin jalan tengah atau yang dalam bahasa inggris dikenal dengan istilah The Doctrin of the mean atau The Golden. Ibnu Miskawaih secara umum memberikan pengertian pertengahan (jalan tengah) tersebut antara lain dengan keseimnangan, harmoni, utama, mulia, atau posisi tengah antara ekstrem kelebihan dan ektrem kekurangan masingmasing jiwa manusia. Empat karakter, yang menjadi pondasi bagi pengembangan karakter mulia manusia yakni al-Iffat (menahan diri/self control), al-Syaja'at (keberanian), dan al-Hikmat (kebijaksanaan) serta al- Adalat (keadilan). Penjelasannya dalam tabel dibawah ini: 
Tabel 2. Empat karakter yang Menjadi Pondasi Bagi Pengembangan Karakter Mulia Manusia

\begin{tabular}{lll}
\hline $\begin{array}{l}\text { Ekstrem Kekurangan } \\
\text { (Al-Tafrith) }\end{array}$ & $\begin{array}{l}\text { Posisi Tengah } \\
(\text { Al-Wasath })\end{array}$ & $\begin{array}{l}\text { Ekstrem Kelebihan } \\
\text { (Al-Ifrath) }\end{array}$ \\
\hline Kedunguan (al-Balab) & Kebijaksanaan(al-Hikmah) & Kelancangan (al-safah) \\
\hline Pengecut (al-Jubn) & Keberanian (al-Syaja'ab) & Nekat (al-Tathawmur) \\
\hline Dingin Hati (al-Khumud) & $\begin{array}{l}\text { Menahan Diri/ menjaga kesucian } \\
(\text { al-Iffät })\end{array}$ & Rakus/ loba (al-Syarah \\
\hline
\end{tabular}

Namun, tidak semua ulama setuju dengan pembagian karakter menurut skema yang dikembangkan oleh Ibnu Maskawaih. Menurut Ahmad Amin ada sebagian keutamaan yang tidak berada di tengah-tengah dua ekstrem yang tercela, misalnya keberanian tidak berada diantara sifat nekat dan pengecut, melainkan lebih dekat dengan nekat. Begitu juga dengan dermawan lebih dekat ke karakter boros dari pada kikir (Abidin, 2014).

Akan tetapi, terkait dengan konsep watak manusia, penulis setuju dengan pendapat Ibnu Miskawaih yang melandaskan pilihannya pada pendapat Aristoteles. Tidak ada keburukan yang melekat abadi pada diri seseorang. Semua orang hatta dengan watak buruk sekalipun dapat berubah dengan pendidikan. Pengajaran dan pendidikan yang berkelanjutan serta bimbingan yang baik yang diupayakan manusia tentulah akan memberi pengaruh, walaupun kadarnya berbeda terhadap bermacam-macam orang. Ada di antara mereka yang menerima pendidikan dengan cepat, sedang sebagian yang lain menerimanya dengan lambat untuk menuju keutamaan.

\section{PENUTUP}

Dari uraian diatas dapat diperoleh kesimpulan bahwa Ibnu Miskawaih adalah seorang filsuf besar islam yang sebagian besar keilmuannya diperoleh melalui jalan membaca. Dengan demikian Ibnu Miskawaih dapat disebut sebagai seorang otodidak yang sukses. Dari banyak karya-karyanya, pemikiran Ibnu Miskawaih sangat dipengaruh oleh filsafat Yunani, peradaban Pesia, ajaran syariat islam dan pengalaman pribadi. Walaupun tidak ditemukan satupun yang mebahas secara khusus tentang pendidikan karakter, namun dalam beberapa karyanya dinilai banyak berhubungan dengan pendidikan. Ibnu Miskawaih sendiri mengakui hakikat dan fungsi dari pendidikan adalah untuk membentuk kepribadian diri manusia sehingga terbentuk manusia yang memiliki malakah dan karakter terpuji.

Adapun saran untuk penelitian selanjutnya, hemat penulis bahwa selain masalah etika, pemikiran Ibnu Miskawaih masih banyak yang perlu dikaji lagi seperti halnya metafisika, psikologi, dan filsafat sosialnya. Pengkajian lebih luas dan mendalam tentang pemikiran filsafat 
Miskawaih akan besar faedahnya bagi bangsa kita Indonesia yang tengah melakukan pembangunan menuju tercapainya manusia yang seutuhnya.

\section{REFERENSI}

Abidin, Zainal. (2014) "Konsep Pendidikan Karakter Islam Menurut Ibnu Miskawaih dan Implikasinya Bagi Pendidikan Karakter Indonesia” 14, no. 02 (TAPIS): 269-290.

Ahmad Azhar Basyir. (1983). Miskawaih: Riwayat dan Pemikiran Filsafatnya. Yogjakarta: Nur Cahaya.

Busyairi Majidi. (1997). Konsep Pendidikan Para Filsof Muslim. Yogjakarta: Al-Amin Press.

Hariyanto, and Febriana Anjaryati. (2016). "Character Building: Telaah Pemikiran Ibnu Miskawaih Tentang Pendidikan Karakter” 1, no. 1 (JPII): 111-118.

Heri Gunawan. (2014). Pendidikan Islam: Kajian Teoritis dan Pemikiran Tokoh. Bandung: Rosdakarya.

Istigfarotul Rahmaniyah. (2010). Pendidikan Etika: Konsep Jiwa Dan Etika Perspektif Ibnu Miskawaih Dalam Konstribusinya Di Bidang Pendidikan. Malang: UIN-Malang Press.

Mahmud. (2011). Pemikiran Pendidikan Islam. Bandung: Pustaka Setia.

Maragustam. (2014). Filsafat Pendidikan Islam: Menuju Pembentukan Karakter Menghadapi Arus Global. Yogjakarta: Kurnia Kalam Semesta.

Miskawaih, Ibn. (1994). Menuju Kesempurnaan Akblak. Translated by Helmi Hidayat. Bandung: Mizan.

Sujadi, E. (2017). Penerapan Pendidikan Karakter Cerdas Format Kelompok untuk Meningkatkan Nilai Kejujuran Mahasiswa Bimbingan Konseling Islam (BKI) Institut Agama Islam Negeri (IAIN) Kerinci. Tarbawi : Jurnal Ilmu Pendidikan, 13(1), 97-108

Sujadi, E., \& Wahab, M. (2018). Strategi Coping Korban Bullying. Tarbawi : Jurnal Imu Pendidikan, 13(2), 21-32.

Unayah, Nunung, and Muslim Sabarisman. "Fenomena Kenakalan Remaja Dan Kriminalitas" 1, no. 02 (2015): 121-140.

Wahyu Murtiningsih. (2014). Para Filsuf dari Plato Sampai Ibnu Bajjah. Yogjakarta: IRCiSoD. 